\title{
KEPEMIMPINAN SITUASIONAL DAN MOTIVASI TERHADAP KINERJA PEGAWAI SEKRETARIAT DPRD KOTA DEPOK
}

\section{(THE INFLUENCE OF SITUATIONAL LEADERSHIP AND WORK MOTIVATION TOWARD EMPLOYEES PERFORMANCE OF SEKRETARIAT DPRD KOTA DEPOK)}

\author{
Oleh: \\ Karno \\ Sekolah Tinggi Ilmu Ekonomi IPWI Jakarta \\ basukarno.ipwija@yahoo.com
}

\begin{abstract}
The purpose of this study was to analyze the influence of situational leadership and work motivation toward Employees performance of Sekretariat DPRD Kota Depok. Sensus research was conduct where the 44 respondents were selected. The Multiple Linear Regression is an analysis method has taken. The Situational Leadership has an effect on the Employees Performance. Work motivation has an effect on the Employees Performance.
\end{abstract}

Keywords: Situational Leadership, Work Motivation, Employee Performance.

\section{ABSTRAK}

Tujuan penelitian ini untuk memahami pengaruh kepemimpinan situasional dan motivasi kerja terhadap kinerja Pegawai Sekretariat DPRD di Kota Depok. Penelitian sensus dilakukan dimana 44 responden dipilih. Regresi Linier Berganda merupakan metode analisis yang digunakan. Kepemimpinan Situasional berpengaruh terhadap Kinerja Pegawai. Motivasi kerja berpengaruh terhadap Kinerja Pegawai.

Kata kunci: Gaya Kepemimpinan, Motivasi Kerja, Kinerja Pegawai

\section{PENDAHULUAN}

Sumber daya manusia merupakan factor produk paling penting dalam organisasi. Keberadaan sumber daya manusia dimaksudkan supaya aktivitas manajemen atau organisasi dapat berjalan dengan baik. Oleh karena itu organisasi harus memiliki pimpinan dan pegawai yang memiliki pengetahuan, keterampilan tinggi untuk mengelola unit kerjanya agar kinerja pegawai meningkat. Dengan kinerja pegawai akan membawa kemajuan bagi organisasi. 
DPRD Kota Depok adalah merupakan lembaga perwakilan rakyat daerah yang berkedudukan sebagai unsur penyelenggara pemerintahan daerah kota. Adapun tugas dan fungsi Anggota DPRD adalah menjalankan fungsi legislasi, fungsi anggaran, dan fungsi pengawasan. Agar Anggota DPRD mampu melaksanakan tugas-tugas dengan baik perlu dukungan dari Sekretariat DPRD.

Sekretariat DPRD sangatlah penting untuk mendukung Anggota DPRD dalam menjalankan fungsi legislatif, fungsi anggaran dan fungsi pengawasan secara efektif dan efisien. Untuk itu pegawai yang mampu menjalankan dan mengelola organisasi yang berhubungan linier positif bagi keberhasilan organisasi.

Kinerja pegawai dapat terhambat karena berbagai hambatan yang muncul. Hal negatif yang dapat menghambat dan menurunkan kinerja pegawai bisa berasal dari pegawai ataupun lingkungannya. Menurunnya semangat pegawai untuk menggapai prestasi kerja, kurangnya ketepatan waktu penyelesaian tugas, ketidaktaatan pada peraturan merupakan beberapa hal yang ada pada diri pegawai. Selain itu juga ada penyebab yang berasal dari lingkungan kerja, salah satunya adalah tidak adanya contoh teladan pimpinan yang dijadikan acuan. Motivasi yang ada dalam diri pegawai dengan berbagai macam ragamnya dan keberadaan pimpinan disatu sisi dapat menghambat kinerja tetapi disisi lain justru sebaliknya yaitu dapat mendorong peningkatan kinerja.

Purwanto (2009: 50) mengatakan bahwa motivasi kerja pegawai dapat muncul apabila beberapa hal berikut dapat sudah ada dan dilaksanakan, yaitu:

(1) Adanya bimbingan dari pimpinan terhadap pegawai secara periodik, teratur dan terus menerus,
(2) Prestasi yang dicapai pegawai mendapat penghargaan yang sesuai atau wajar,

(3) lingkungan kerja terjamin kemanan dan kenyamanannya,

(4) Sarana prasarana di tempat kerja lengkap atau memadai,

(5) Ada sosialisasi tentang peningkatan jenjang karier pegawai yang dilakukan secara periodik,

(6) Pemberian gaji, upah, honorarium atau bentuk kompensasi lainnya diberikan tepat waktu sesuai dengan yang telah ditetapkan sebelumnya.

Berdasarkan observasi di kantor Sekretariat DPRD Kota Depok Provinsi Jawa Barat, lemahnya kinerja pegawai utamanya terjadi karena beberapa temuan yaitu sebagai berikut: (1) Motivasi kerja pegawai yang belum baik karena akibat dari pemenuhan kebutuhan kemanan khususnya yang berkenaan dengan jenjang karier yang belum mendapat jaminan dari organisasi dan minimnya penghargaan bagi pegawai diantaranya terlihat dari adanya pegawai yang tidak mendapatkan penghargaan mesikpun sudah bekerja di organisasi selama rentang waktu yang lama yaitu puluhan tahun dengan disiplin yang baik, (2). Kepemimpinan yang ada diorganisasi belum mampu memuaskan pegawai terlihat dari masih adanya hubungan kurang harmonis secara vertical antara pimpinan dengan bawahan maupun secara horizontal berupa hubungan sosial di antara para pegawai.

\section{TUJUAN PENELITIAN}

Penelitian ini bertujuan untuk mengetahui, membuktikan dan menjelaskan ada tidaknya pengaruh kepemimpinan situasional dan motivasi kerja terhadap kinerja pegawai di sekretariat DPRD Kota Depok. 
TELAAH LITERATUDR DAN PENGEMBANGAN HIPOTESIS Kepemimpinan Situasional

Keberadaan pimpinan menjadi bagian yang sangat penting dalam pelaksanaan kegiatan organisasi. Pimpinan dengan gayanya masing-masing menjadi bagian yang tidak dapat dikesampingkan apalagi di suatu instansi pemerintahan karena menentukan dapat tidaknya tujuan yang telah ditetapkan sebelumnya untuk dicapai. Tepat tidaknya kepemimpinan dan gaya yang diperlihatkan dapat dilihat secara tidak langsung atau tidak langsung. Baik buruknya kepemimpinan secara tidak langsung dapat dinilai dari unjuk kerja atau tampilan kerja dari pegawainya sedangkan secara langsung dapat dilihat dari kebijakan dan tindakan pimpinan dalam memberikan motivasi kepada pegawai yang dipimpinnya.

Gaya kepemimpinan situasional merupakan salah satu bentuk gaya kepemimpinan yang dapat diterapkan oleh pimpinan. Gaya kepemimpinan ini bersifat dan dipengaruhi secara sosiologis dan psikologis. Dari sudut pandang sosiologis, kepemimpinan diwujudkan dalam bentuk hubungan sosial pimpinan-pegawai dalam organisasi dan hubungan pimpinanlingkungan masyarakat. Sikap dan tingkah laku yang diperlihatkan pimpinan tidak dapat dilepaskan dari kondisi adat istiadat ataupun kebiasaan-kebiasaan lingkungan asalnya. Hubungan sosial yang diperlihatkan pimpinan-pegawai di dalam organisasi dan hubungan pimpinanlingkungan masyarakat yang baik menunjukkan gaya yang diterapkan pimpinan yang bersangkutan memiliki indikasi yang baik. Dari sudut pandang psikologis, wujud gaya kepemimpinan tergambar dari sifat-sifat dan kepribadian yang diperlihatkan oleh pimpinan yang bersangkutan dan pegawai yang dipimpinnya.
Kepemimpinan situasional merupakan gaya kepemimpinan yang didasarkan atas hubungan social dan psikologis. Kondisi hubungan tersebut didasarkan pada tiga hal mendasar yaitu besar kecilnya tingkat bimbingan dan arahan yang diberikan atau dari pemimpin, tinggi rendahnya dukungan sosioemosional daripemimpin kepada bawahannya, dan tinggi rendahnya kesiapan dari bawahan dalammelaksanakan tugas, fungsi dan tujuan yang dibebankan kepadanya.

Kematangan merupakan kunci dalam kepemimpinan situasional. Matang tidaknya pemimpin dalam kepemimpinan situasional termaktub pada kemampuan dan kemauan pemimpin untuk memikul tanggung jawab dengan mengarahkan perilaku diri sendiri dalam situasi tertentu. Oleh karena itu kematangan sebagai sebuah konsep dasar kepemimpinan situasional sangat berkaitan dengan seberapa besar keinginan pemimpin dalam menerjemahkan tugas dan seberapa kuat keinginan untuk mencapainya.

Konsep kepemimpinan situasional yang dikemukakan Siagian (2008: 29) berawal dari pemikiran bahwa kepemimpinan merupakan bentuk dinamika hubungan kerja unsur pimpinan dan staf. Baik buruknya kepemimpinan situasional terlihat dari kadar bimbingan dan arahan yang ditunjukkan pemimpin; perilaku hubungan timbal balik diantara pemimpin dengan pengikut atau bawahan; dan derajat kesiapan bawahan untuk melaksanakan tugas-fungsi-tujuan yang dibebankan kepadanya. Baik buruknya kepemimpinan situasional menurut Siagian, (2008: 17) dapat dilihat dari indicator sebagai berikut:

1 Telling-Memberitahu

2 Participating-Partisipatif

3 Selling-Menjual, Menjelaskan

4 Delegating-Delegasi 
Kepemimpinan situasional menurut model ini menuntut pimpinan untuk dapat melihat dan mempertimbangkan situasi sebelum memutuskan model kepemimpinannya. Penerapan kepemimpinan didasarkan pada kontijensi situasional yaitu mempertimbangkan kesiapan bawahan dengan mempertimbangkan kemampuan bawahan dalam memahami tujuan organisasi secara maksimal diiringi dengan kesediaan dan keinginan untuk mengemban tanggung jawab yang diberikan dalam rangka pencapaian tujuan bersama.

\section{Motivasi Kerja}

Motivasi menurut Winardi (2001: 6), adalah kekuatan potensial yang ada dalam diri manusia, yang dapat kembangkan baik oleh dirinya sendiri secara mandiri maupun dengan dorongan kekuatan luar khususnya yang berkaitan dengan imbalan baik dalam bentuk materi maupun nonmateri.

Salah satu teori motivasi yaitu yang dikemukakan Maslow dalam Gibson, (1997: 110) mendasarkan pada factor kebutuhan dalam bentuk hierarki yaitu sebagai berikut:

1. Kebutuhan Fisiologis

Merupakan kebutuhan dalam diri seseorang dalam rangka mempertahankan hidup. Hal ini tergambar dari terpenuhi tidaknya kebutuhan dasar atau primer yaitu sandang, pangan, dan papan. Kebutuhan fisiologis dipandang sebagai kebutuhan yang paling awal karena kebutuhan ini diperlukan sepanjang waktu, tidak terhenti selama manusia masih ada di dunia atau belum menemui ajalnya. Tidak terpenuhinya kebutuhan fisiologis membuat seseorang tidak dapat hidup secara normal. Disebut juga sebagai kebutuhan primer karena diperlukan guna memenuhi kebutuhan dasar manusia yaitu psikologis dan biologis.

2. Kebutuhan Keselamatan dan Keamanan

Kebutuhan ini merupakan jenjang kedua dalam hierarki yaitu diperlukannya rasa aman, tentram, bebas dari rasa takut dan jaminan hidup tua atau masa yang akan datang. Kebutuhan keamanan dan keselamatan dapat dipenuhi dengan adanya perlindungan dari berbagai ancaman baik ancaman fisik, jaminan kesehatan dan jaminan hari tua. Kebutuhan ini lebih banyak menjadi tanggung jawab organisasi dalam pemenuhannya. Pegawai akan merasa terpenuhi kebutuhannya manakala pegawai merasakan situasi yang menyenangkan dan terbebas dari rasa takut.

3. Kebutuhan Sosial

Merupakan kebutuhan yang menunjukkan hubungan harmonis dengan kolega atau rekan kerja. Bentuknya dapat berupa rasa cinta, kasih sayang, persahabatan, interaksi, saling memiliki, kekeluargaan dan sosialisasi.

4. Kebutuhan Penghargaan

Wujud ingin dihormati, dihargai, pengakuan yang memberikan kepuasan batin.

5. Kebutuhan Aktualisasi Diri

Aktualisasi diri merupakan bentuk unjuk kemampuan dan keahlian yang menunjukkan potensi yang sesungguhnya dari seseorang.

\section{Kinerja}

Kinerja dapat dipahami sebagai hasil kerja yang dicapai dari seorang individu atau dari sekelompok individu tertentu 
dalam melaksanakan tsegenap ugas dan tanggung jawab yang dibebankan organisasi kepada yang bersangkutan didasarkan atas pengetahuan, keterampilan, kecakapan, pengalaman dan kesungguhan serta waktu.

Menurut Mangkunegara (2001); kinerja atau disebut juga prestasi kerja adalah capaian hasil kerja secara kualitaskuantitas yang berhasil dicapai seorang individu karyawan dalam melaksanakan setiap tugas-tugasnya sesuai dengan tanggung jawab kewajiban yang dibebankan kepadanya".

Kinerja (performance) merupakan akhir dari sebuah proses yang menunjukkan suatu hasil tertentu dari yang telah dikerjakan dalam rangka mewujudkan tujuan organisasi. Pelaksanaan tugas tersebut dilakukan dengan legal, tidak melanggar hokum, sesuai moral pada umumnya dan minimal setara dengan tanggung jawab yang dibebankan kepadanya.

\section{Kerangka Pemikiran}

Kerangka Berpikir Pengaruh Kepemimpinan Situasional yang diterapkan pimpinan, Motivasi Kerja yang dimiliki pegawai terhadap Kinerja Pegawai, adalah sebagai berikut:

Gambar 1

Kerangka Pemikiran

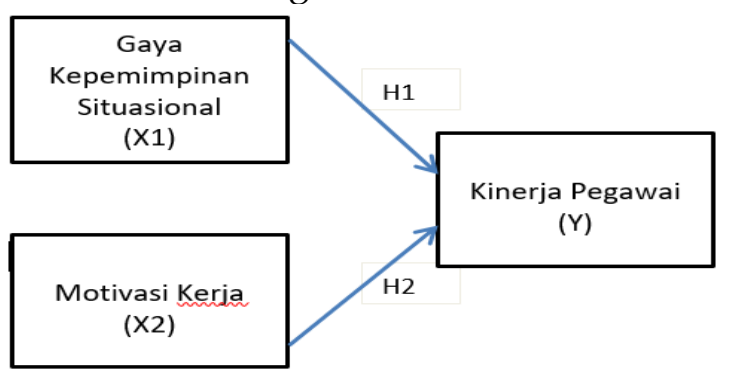

Hipotesis penelitiannya adalah sebagai berikut :
$\mathrm{H} 1$ = Kepemimpinan situasional ada pengaruhnya terhadap Kinerja Pegawai di Sekretariat DPRD Kota Depok.

H2 = Motivasi kerja ada pengaruhnya terhaap Kinerja Pegawai di Sekretariat DPRD Kota Depok.

\section{METODE PENELITIAN \\ Lokasi dan Waktu Penelitian}

Penelitian ini dilaksanakan kepada pegawai kantor sekretartiat DPRD Kota Depok. Pemilihan lokasi ini didasarkan pada data dan informasi yang dibutuhkan relevan dengan pokok permasalahan yang menjadi obyek peneliti, yaitu kinerja pegawai atas dasar kepemimpinan situasional pegawai dan motivasi kerja pegawai. Penelitian dijalankan dalam kurun waktu tiga bulan. Pelaksanaannya dari bulan Agustus sampai dengan bulan November 2018.

\section{Sampel}

Seluruh populasi yaitu Pegawai dalam hal ini yang berstatus PNS pada Kantor Sekretariat DPRD Kota Depok sebanya 40 orang dipergunakan sebagai sampel penelitian. Oleh karena itu metode samplingnya dalah sampling jenuh sehingga penelitiannya disebut sensus.

\section{Jenis dan Sumber Data}

Sebagai bahan analisis untuk memahami, mengetahui, menguji dan menganalisis kebenaran sebuah hipotesis, maka diperlukan data yang menurut sumbernya adalah sebagai berikut:

1) Data Primer

Data hasil angket yang diberikan kepada pegawai Sekretariat DPRD Kota Depok.

2) Data Sekunder

Data ini diperoleh dari literatur yang ada baik berupa dokumen organisasi 
maupun jenis laporan lain yang berkaitan dengan masalah dalam penelitian.

\section{Teknik Pengumpulan Data}

Teknik pengumpulan data banyak macamnya, dimana dalam penelitian ini meliputi:

1) Observasi

Dilakukan dengan melakukan pengamatan secara langsung dan secara tidak langsung pada obyek yang diteliti.

2) Kuesioner

Pemberian seperangkat daftar pertanyaan tertulis kepada responden (Sugiyono, 2006: 158). Kuesioner yang berisi daftar pertanyaan disebarkan kepada responden yang diteliti untuk mendapatkan data primer.

3) Dokumentasi

Dokumentasi dilakukan dengan menelaah data tentang jumlah pegawai dan karakteristiknya, struktur organisasi lengkap dengan alurnya dan data lainnya. Dokumentasi dilaksanakan dengan melihat atau mengumpulkan dokumen-dokumen resmi dari obyek penelitian . Data yang terkumpul selanjutnya dipakai sebagai pendukung dalam melakukan pembahasan hasil penelitian.

\section{Metode Analisis}

Analisis data menggunakan software SPSS dimana analisis yang digunakan adalah analisis kuantitatif yang berupa Analisis Regresi Linier Ganda.

\section{HASIL PENELITIAN DAN PEMBAHASAN}

Berdasarkan hasil analisi koefisien determinasi bahwa Kepemimpinan Situasional pemimpin dan Motivasi kerja pengawai pengaruhnya terhadap Kinerja sebesar 0,471 yang berarti bahwa model hasil analisis mampu menjelaskan 47,1\% kinerja pegawai karena adanya factor Kepemimpinan Situasional dan Motivasi kerja. Hasil output yang menunjukkan pengaruh tersebut adalah:

Tabel 1

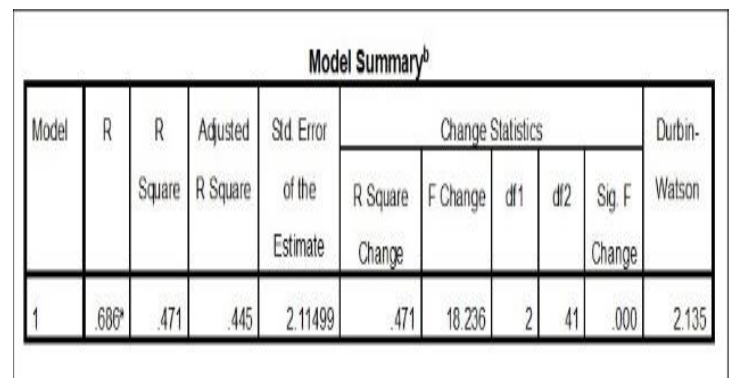

Berdasarkan hasil uji hipotesis dengan uji $\mathrm{F}$ bahwa pengaruh Kepemimpinan Situasional dan Motivasi hasilnya signifikan karena nilai Fhitung sebesar 18,236 memiliki tingkat signifikansi sebesar 0,000 .

Tabel 2

ANOVA $^{\mathrm{a}}$

\begin{tabular}{|l|r|r|r|c|c|}
\hline Model & $\begin{array}{r}\text { Sum of } \\
\text { Squares }\end{array}$ & df & $\begin{array}{c}\text { Mean } \\
\text { Square }\end{array}$ & $F$ & Sig. \\
\hline \multicolumn{1}{|c|}{ Regression } & 163.144 & 2 & 81.572 & 18.236 & $.000^{\circ}$ \\
1 Residual & 183.401 & 41 & 4.473 & & \\
$\quad$ Total & 346.545 & 43 & & & \\
\hline
\end{tabular}

Hasil analisis selanjutnya adalah sebagai berikut:

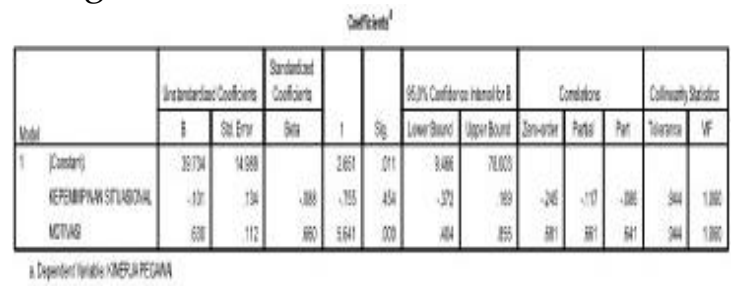

Berdasarkan hasil analisis persamaan regresi bahwa hasilnya yaitu:

$$
\hat{Y}=39,734-0,101 X 1+0,630 X 2
$$

Persamaan tersebut berarti bahwa nilai variabel $Y$ (Kinerja pegawai) dipengaruhi oleh nilai variabel $X 1$ (kepemimpinan situasional) dan $\mathrm{X} 2$ (motivasi kerja). 
- Koefisien regresi variabel X1 (Kepemimpinan Situasional) sebesar 0,101 dan $\mathrm{t} X 1 \mathrm{Y}=-0,755$ memiliki tingkat signifikansi sebesar 0,454 yang berarti hasilnya tidak signifikan.

- Koefisien regresi variabel X2 (Motivasi) sebesar 0,630 dan $\mathrm{t} X 2 \mathrm{Y}=$ 5,641 memiliki tingkat signifikansi sebesar 0,000 yang berarti hasilnya signifikan.

\section{KESIMPULAN}

1. Variabel Kepemimpinan Situasional pemimpin dalam hal ini tidak memiliki pengaruh terhadap kinerja pegawai Sekretariat DPRD Kota Depok.

2. Motivasi pegawai dalam hal ini memiliki pengaruh dengan slope positif terhadap kinerja pegawai Sekretariat DPRD Kota Depok

\section{SARAN}

1. Kepala Kantor Sekretariat DPRD Kota Depok Provinsi Jawa Barat disarankan agar terus berupaya memupuk kerjasama yang baik dengan para pegawai sebagai bawahannya serta senantiasa memotivasi pegawainya dengan memberikan penghargaan kepada pegawai yang berprestasi dengan tidak lupa melakukan pengawasan yang bersifat mendidik.

2. Perlu dilakukan penelitian lebih lanjut dengan model, pengukuran, dan obyek yang lebih luas untuk mendapatkan temuan yang lebih baik lagi.

\section{DAFTAR PUSTAKA}

Harsey dan Blanchard (dikutip oleh Miftah Thoha.1996:64http://www.jurnal.com /20 13/09/teori kepemimpinansituasional).

Musanef. $1987 . \quad$ Manajemen Kepegawaian di Indonesia. PT Gunung Agung, Jakarta

Nawawi. 2000. ManajemenSumber Daya Manusia: $\quad$ Untuk Yang Kompetitif. Cetakan pertama. Yogyakarta: Gadjah Mada University Press.

Siagian. 2008. Manajemen Sumber Daya Manusia, Edisi 1 Cetakan 16, Bumi Aksara, Jakarta.

Sugiyono. 2004. Metode Penelitian Kuantitatif, Kualitatif dan R\&D. Alfabeta, Bandung.

Suprihanto. 2008. Penilaian Kepuasan kerja dan Pengembangan Pegawai. Edisi Pertama BPFE, Yoyakarta.

Wursanto 1G. 1988. Manajemen Kepegawaian. Kanisius, Jakarta. 